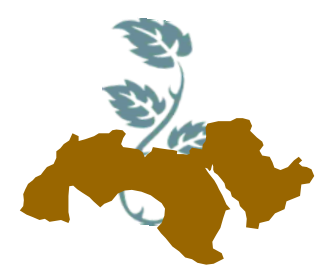

\title{
INFLUENCE OF IN-OVO INJECTION OF SELENIUM NANOPARTICLES AND SELENOMETHIONINE ON GROWTH PERFORMANCE AND PHYSIOLOGICAL PARAMETERS OF BROILER CHICKS
}

\author{
Abd El-Fatah ${ }^{1}$, M.M.; I. El-Wardany ${ }^{2}$; E.A. Abdallah ${ }^{1}$ and Marwa Sh. Abdo ${ }^{2}$ \\ 1- Poultry Breeding Research Dept., Animal Prod. Res. Inst., Agric. Res. Center, Ministry of \\ Agric., Dokki, Giza, Egypt \\ 2- Poultry Production Dept., Fac. of Agric., Ain Shams Univ., Cairo, Egypt
}

Keywords: Nano selenium, Growth performance, Blood parameters, Broiler chicks

\section{ABSTRACT}

This study was conducted to investigate the effect of in ovo injection of broiler eggs with different levels and forms of selenium on growth performance and some blood parameters of post hatched chicks. A total of 300 fertilized eggs obtained from a commercial Arbor Acres broiler breeder flock, were used in the present experiment. They were divided randomly into six treatment groups, 50 eggs each. The first one was kept as a control- non injected group, the second group (sham) injected with phosphate buffered saline (PBS), the 3rd and 4th groups were injected with selenium nanoparticles (SeNPs) at 10 and 20 ug/egg, while the 5th and 6th groups were injected with organic selenium (Se-Methionine) at 50 and $100 \mathrm{ug} / \mathrm{egg}$, respectively. All eggs were incubated in a forced draught incubator at the recommended temperature, relative humidity and turning patterns .The in ovo injection procedure was done at the $16^{\text {th }}$ day of incubation. The criteria of response includes: live body weight, weight gain, feed consumption, feed conversion ratio, total protein, albumin, globulin, A/G ratio, cholesterol, triglyceride, $\mathrm{HDL}$ and glucose. The results showed that the supplementation of Se did not significantly affect growth performance traits. Supplementation of nano-Se increased plasma concentrations of total protein, albumin and HDL, and decrease glucose, however, no significant differences in globulin, $A / G$ ratio, cholesterol and triglyceride levels. It can be concluded that the use of $20 \mathrm{ug}$ /egg of Nano-Se caused an improvement of growth performance and feed conversion ratio without negative effects on blood constituents.

\section{INTRODUCTION}

Selenium is a trace element essential in animal nutrition and exerts multiple actions related to animal production, fertility, and disease prevention (Mervyn, 1985). Selenium is an integral part of the enzyme glutathione peroxidase, which serves as an antioxidant enzyme that helps to control levels of hydrogen peroxide and lipid peroxides that are produced during normal metabolic activity (Rotruck et al 1973). In addition, dietary selenium is essential for the activity of virtually all arms of the immune system (Surai and Dvorska, 2002).

The NRC (1994) recommendations established a minimum level of $0.15 \mathrm{mg} / \mathrm{kg}$ for selenium supplementation of broilers. There is widespread concern in the animal industries that the NRC minimum recommendation is not sufficient to prevent production losses due to selenium deficiency syndromes; therefore there is continued research into alternative selenium sources and alternative selenium supplementation levels. The bioavailability of selenium is associated with its physical form. Currently, sodium selenite is the most common selenium source used in animal feeds, whereas organic forms such as selenium-enriched yeast and seleno-methionine are also used in many countries (Federal Register, 2002; European Union, 2006 and Ministry of Agriculture, 2008).

The environmental stress can decrease production and all other important economical traits in animal husbandry. The stress is caused by free radicals and reactive oxygen species. Gaseous exchanges and high metabolic rates during em- 
bryonic development can lead to the production of reactive oxygen species (ROS) free radicals (Halliwell, 1994). These free radicals can cause cellular damage leading to peroxidation. Antioxidants play an important role in combating these substances and providing protection to cells and the developing embryo overall (Surai et al 1996). Rapid growth coupled with a high nutrient requirement, especially during late embryogenesis, may make in ovo feeding of supplemental nutrients beneficial to poultry. Supplementing the amnion with appropriate nutrients is a novel way to feed critical dietary nutrients to embryos.

Selenium has long been known to be toxic and there are concerns about its effect on animals and animal products. To ensure feed safety, maximum levels for selenium in complete feeds have been set at $0.5 \mathrm{mg} / \mathrm{kg}$ in the European Union (2004) and China (Ministry of Agriculture, 2010) and 2.0 $\mathrm{mg} / \mathrm{kg}$ for the United States (AAFCO, 2011). With the recent development of nanotechnology, nanoselenium (nano-Se) has attracted widespread attention because nanometer particulates exhibit novel characteristics such as a large surface area, high surface activity, high catalytic efficiency, strong adsorbing ability, and low toxicity (Wang et al 2007 and Zhang et al 2008). Zhou and Wang (2011) supplemented $0,0.1,0.3$, and $0.5 \mathrm{mg} / \mathrm{kg}$ of nano-Se in diets fed to Guangxi Yellow broilers and concluded that $0.30 \mathrm{mg} / \mathrm{kg}$ of nano-Se was effective in improving feed conversion, the selenium content of tissues, and the quality of the meat.

The main objective of the present study was to assess and compare the effect of supplemental selenium sources (as selenomethionine and nano elemental selenium) on growth performance and physiological parameters of broiler chicks.

\section{MATERIALS AND METHODS}

The present study was carried out in The Faculty of Agriculture, Ain Shams University, through April, May and June (2015). The laboratory work of the present study was done at Poultry Breeding Department, Animal Production Research Institute (APRI), Ministry of Agriculture, Dokki, Giza, Egypt.

\section{In Ovo Injection of Graded Levels of Selenium}

A total of 300 fertilized egg of Arbor Acres broiler were used for this study. All eggs were individually numbered and weighed each prior to the beginning of the incubation. Average egg weight was approximately $50 \mathrm{~g}$. Fertile eggs were incu- bated at $37.5^{\circ} \mathrm{C}$ and a relative humidity of 55 to $60 \%$ during $\mathrm{d} 1-18$ and at $36^{\circ} \mathrm{C}$ with relative humidity of $60-65 \%$ during $d 19-21$. On d 6 of incubation, unfertilized eggs or those with early embryonic mortality were discarded. At $16 \mathrm{~d}$ of incubation the eggs were injected into the air sac with $0.1 \mathrm{ml}$ of solutions using a sterile 27 gauge, $20 \mathrm{~mm}$ needle. Immediately after the injection, the hole was sealed with sterile tape. The eggs were randomly divided into six groups, each with 50 eggs. Two sources of Se, Se-Met and Nano-Se, were used

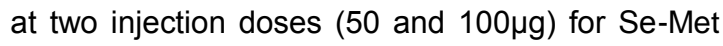
and $(10$ and $20 \mu \mathrm{g})$ for Nano- Se. Sham-control eggs injected with phosphate buffered saline(PBS) and non-injected eggs were also included. The hatched chicks were used for a grow-out study

\section{Preparation of Se Solutions}

One $\mathrm{ml} 25 \mathrm{mM}$ sodium selenite was mixed with $4 \mathrm{ml} 25 \mathrm{mM}$ GSH containing $20 \mathrm{mg}$ BSA. The mixture $\mathrm{pH}$ was adjusted to 7.2 with $1.0 \mathrm{M}$ sodium hydroxide, instantly forming Nano red elemental Se and oxidized glutathione (GSSG). The red solution was dialyzed against double distilled water for 96 hours, the water changed every 24 hours to separate GSSG from the Nano-Se. The final solution containing Nano-Se and BSA was lyophilised and stored at room temperature. X-ray photoelectric energy spectra (XPS) showed the binding energy of Se 3d was $55.3 \mathrm{eV}$ indicating Se0. Transmission Electron Microscopy (TEM) showed the size of red elemental Se was between $20 \sim 60 \mathrm{~nm}$.

\section{Se Injection Procedure}

At day 16 of incubation, eggs were removed from the incubator and candled for viability. Under the candler, the outline of the air cell was traced using a pencil and the location of the embryo was marked. After disinfecting the eggshell with an alcohol swab, a small hole was drilled on the large end of the egg, above the air cell. Using a 23 gauge, $1 \frac{1}{2}$ " needle, $0.1 \mathrm{ml}$ of respective Se solution was injected into the yolk. The injection site on the eggshell was sealed with glue and eggs were placed back into the incubator with settings according to standard hatchery practices.

\section{Birds and housing}

The post-hatch chicks from each treatment were weighed and maintained in their same respective groups for a period of 5 weeks. The ex- 
perimental birds were housed in Six-tiered, wellventilated battery cages provided with artificial lighting. The standard management practices were adopted, and they were uniform for all the treatment groups. All the chicks in the various treatments were fed ad libitum a common commercial ration. The chicks were fed with broiler starter ration from 0 to 10 days and broiler grower ration from $11 \mathrm{~d}$ to 35 days of age. Clean drinking water was provided ad libitum. The ingredient and nutrient composition of the experimental rations are presented in Table (1).

Table 1. Ingredients and the chemical Composition of the experimental diets

\begin{tabular}{|c|c|c|}
\hline $\begin{array}{c}\text { Composition } \\
\text { (per } 100 \text { kg) }\end{array}$ & $\begin{array}{c}\text { Starter } \\
\text { (1-10 } \\
\text { day) }\end{array}$ & $\begin{array}{c}\text { Grower } \\
\text { (11-35 day) }\end{array}$ \\
\hline Yellow corn & 52.28 & 63.19 \\
\hline Soybean meal (44\% CP) & 34.00 & 22.5 \\
\hline Corn gluten $(60 \% \mathrm{CP})$ & 6.00 & 6.30 \\
\hline Soy bean oil & 3.00 & 4.00 \\
\hline Di-calcium phosphate & 1.84 & 1.59 \\
\hline Lime stone & 1.43 & 1.10 \\
\hline L-Lysine $\mathrm{HCl}$ & 0.32 & 0.28 \\
\hline DI-Methionine & 0.26 & 0.17 \\
\hline Sodium chloride & 0.24 & 0.24 \\
\hline Sodium bicarbonate & 0.23 & 0.23 \\
\hline Vitamins Premix * & 0.10 & 0.10 \\
\hline Minerals Premix ${ }^{* *}$ & 0.30 & 0.30 \\
\hline Total & 100.00 & 100.00 \\
\hline Calculated analysis** & & \\
\hline Crude protein & 23.17 & 21.25 \\
\hline $\begin{array}{l}\text { Metabolizableenergy } \\
\text { (Kcal/kg) }\end{array}$ & 3100 & 3110 \\
\hline Ether extract & 5.63 & 5.08 \\
\hline Crude fiber & 3.80 & 3.45 \\
\hline Calcium & 1.04 & 0.90 \\
\hline Av. Phosphorus & 0.50 & 0.45 \\
\hline Lysine & 1.44 & 1.24 \\
\hline Methionine & 0.68 & 0.60 \\
\hline Methionine+cystine & 1.06 & 0.95 \\
\hline Sodium & 0.15 & 0.16 \\
\hline
\end{tabular}

*Supplied per kg of diet: Vit. A, 11000 IU; Vit. D3, 5000 IU; Vit. E, 50 mg; Vit K3, 3 mg; Vit. B1, 2 mg; Vit. B2 6 mg; B6 3 $\mathrm{mg}$; B12, $14 \mathrm{mcg}$; Nicotinic acid 60mg; Folic acid $1.75 \mathrm{mg}$, Pantothenic acid $13 \mathrm{mg}$; andBiotin $120 \mathrm{mcg}$

** Supplied per kg of diet: Choline $600 \mathrm{mg}$; Copper $16 \mathrm{mg}$; Iron $40 \mathrm{mg}$;

Manganese. $120 \mathrm{mg}$; Zinc $100 \mathrm{mg}$ and lodine $1.25 \mathrm{mg}$

\section{Physiological traits}

\section{Blood parameters}

Blood samples were collected from three chicks per each replicate at $35 \mathrm{~d}$ of age to evaluate the blood chemical constituents. For each sample, $5 \mathrm{ml}$ blood was collected by brachial vein puncture in heperinized tubes. The tubes were centrifuges at $4000 \mathrm{rpm}$ for 15 minutes and clear plasma was separated then, stored in a deep freezer at $-20^{\circ} \mathrm{C}$ until the time of biochemical analysis.

To determine total cholesterol content, a sample of $0.5 \mathrm{ml}$ plasma was transferred into sterile tube containing $6 \mathrm{ml}$ glacial acetic acid, mixed, and then added $4 \mathrm{ml}$ ferric chloride reagent, shaken and cooling the color was measured at $550 \mathrm{~nm}$ wave length by using the spectrophotometer. The cholesterol value $(\mathrm{mg} / \mathrm{dl})$ was calculated as the sample/ standardx200. Kits was used to determine HDL and LDL according to Lopes-Virella et al (1977) and Steinberg et al (1981), respectively.

Kits were used to determined triglycerides, total protein, albumin, glucose, alkaline phosphates in plasma according to Fossati and Prencipe (1982), Josephson et al (1957), Dumas and Biggs (1972), Baure (1982), Hansen (1966), respectively.

\section{Slaughter traits}

At 1 and $35 \mathrm{~d}$ of age, three chicks per replicate were weighted, sacrificed for slaughtering weights of carcass, breast muscle and internal organs (heart, liver, and lymphoid organs (spleen and Bursa) were recorded to the nearest $0.1 \mathrm{gm}$. The relative weights of these organs were calculated in relation to live body weight.

\section{Statistical analysis}

Statistical differences among treatments were assessed using one way ANOVA, SAS (1999) and with Tukey's Multiple Comparison Test (Instat, Graph Pad Software, San Diego, CA, USA). Statistical significance was set at $P<0.05$.

\section{RESULTS AND DISCUSSION}

\section{Productive performance}

\section{a. Body weight}

Effect of in ovo feeding of selenomethionine and nano selenium at different levels on body 
weights of broilers (0-5 weeks) are shown in Table 2. Body weights recorded at $d 7,14,21,28$ and 35 were not affected by the Se sources or levels. These results are comparable to earlier studies in which supplementation of Se has no significant effect on body weight. Choupani et al (2014) observed that no significant difference in final body weight between nano $\mathrm{Se}$ and sodium selenite or selenomethionine groups, when the basal diet was supplemented with 0 (control), $0.3 \mathrm{mg} / \mathrm{kg}$ Se from sodium selenite, selenomethionine, selenized yeast or nano elemental selenium.

Mohamed et al (2016) compared different sources of selenium, sodium selenite, organic (Selenium Yeast) and Nano selenium, and found that no significant effect on body weight of broiler chicks as a result of supplementing Nano selenium to the diet during the periods of 12-16 weeks of age compared to sodium selenite.

Choct et al (2004) found that there was no difference $(P>0.05)$ in body weight at $d 38$ between treatments when they compare two Se source (sodium selenite and organic selenium as selenised yeast) with two levels $(0.10-0.25 \mathrm{mg} / \mathrm{kg})$ for each.

Payne and Southern (2005) found that body weight was not affected $(P>0.05)$ by Se source or level of supplementation in any period of growth or in the overall data, when the basal diet was supplemented with 0 (control) or $0.30 \mathrm{ppm}$ Se from sodium selenite (SS) or Se-enriched yeast (SY). Edens et al (2001) reported no differences in body weight when broilers were fed diets containing $0.20 \mathrm{ppm}$ Se from SS or SY.

However, El-Said (2015) found that administration of nano Se with different level (20 and 40) ppb at 7 and 14 days of incubation for each level in egg and found an increase in final body weight. Konkov et al (2015) used nano selenium at con- centration of $0.1,0.01$ and $0.001 \mathrm{mg} / \mathrm{kg}$ of daily live weight and found an increase of live body weight in all groups compared with the control, and the optimal concentration of nano selenium is 0.001 $\mathrm{mg} / \mathrm{kg}$ of a bird weight. Senthil et al (2015) evaluated three different diets prepare with control standard diet, sodium selenite $0.3 \mathrm{mg} / \mathrm{Kg}$ diet and selenium nanowires $0.3 \mathrm{mg} / \mathrm{Kg}$ diet from one day of hatch to 6 weeks of age and found that chicken diets with $0.30 \mathrm{mg} / \mathrm{kg}$ was effective in increasing the body weight. Dlouha et al (2008) studied the effects of supplementation of dietary sodium selenite and sodium-enriched alga chlorella on the growth performance of sexed broiler cockerels Ross 308 . The basal diet was supplemented with 0 (control) or $0.3 \mathrm{mg} / \mathrm{kg}$ Se from sodium selenite or Se-Chlorella (Se-CH). Dietary supplementation with $\mathrm{Se}-\mathrm{CH}$ increased body weight. Also, Heindl et al (2010) confirmed that Se addition influenced body weight in 21- and 35-day-old broiler chickens. Significantly higher body weight at 35 days of age was observed in chickens receiving $0.15 \mathrm{mg}$ of $\mathrm{Se}$ from selenium-enriched yeast (Sel-Plex® SP) and $0.3 \mathrm{mg}$ of Se from selenium-enriched yeast contrary to dietary treatment with a lower level of Se from selenium-enriched alga chlorella per $\mathrm{kg}$ of feed. Feeding of selenized yeast increased the live body weight of chickens compared with the controls (Rozbicka- Wieczorek et al 2012).

The lack of concurrence among these studies may be partially explained by differences in basal diets used. Nevertheless, there are other variables such as differences in background of the targeted populations, age, farm hygiene, stressor severity and level of stress response that may influence the efficacy of a Se application and thus it was difficult to directly assess different studies using Se.

Table 2. Effect of in ovo feeding of selenomethionine and nano selenium at different levels on body weight of broilers (0-5 weeks)

\begin{tabular}{|c|c|c|c|c|c|c|}
\hline \multirow{2}{*}{ Treatments } & \multicolumn{7}{|c|}{ Body weight (g) } \\
\cline { 2 - 7 } & Chick weight & $\mathbf{1 w k}$ & $\mathbf{2 ~ w k}$ & $\mathbf{3} \mathbf{~ w k}$ & $\mathbf{4} \mathbf{~ w k}$ & $\mathbf{5} \mathbf{~ w k}$ \\
\hline Control & $40.63^{\mathrm{ab}}$ & $122.358^{\mathrm{ab}}$ & 345.83 & 727.00 & 1264.76 & $1716.33^{\mathrm{ab}}$ \\
PBS & $40.58^{\mathrm{ab}}$ & $114.738^{\mathrm{b}}$ & 335.42 & 728.54 & 1272.17 & $1778.24^{\mathrm{ab}}$ \\
Se Me 50 & $41.00^{\mathrm{a}}$ & $119.075^{\mathrm{ab}}$ & 338.04 & 734.74 & 1225.48 & $1695.00^{\mathrm{b}}$ \\
Se Me 100 & $40.25^{\mathrm{abc}}$ & $125.408^{\mathrm{ab}}$ & 345.42 & 736.46 & 1301.32 & $1792.86^{\mathrm{a}}$ \\
Nano-Se 10 & $39.65^{\mathrm{c}}$ & $128.418^{\mathrm{a}}$ & 326.76 & 730.00 & 1279.64 & $1768.33^{\mathrm{ab}}$ \\
Nano-Se 20 & $40.00^{\mathrm{bc}}$ & $119.630^{\mathrm{ab}}$ & 323.00 & 761.50 & 1244.50 & $1704.80^{\mathrm{ab}}$ \\
\hline SEM & $\mathbf{0 . 2 7}$ & $\mathbf{3 . 4 9}$ & $\mathbf{1 0 . 4 9}$ & $\mathbf{1 9 . 2 5}$ & $\mathbf{2 5 . 6 3}$ & $\mathbf{2 8 . 2 8}$ \\
\hline
\end{tabular}

a, b, c means within the same column with different superscript are significantly different ( $P \leq 0.0001)$. 


\section{b. Body weight gain}

Effect of in ovo feeding of selenomethionine and nano selenium at different levels on body weight gain of broilers (0-5 weeks) are presented in Table 3. It is apparent that there were no significant differences in body weight gain as a result of Se injection.

These results are in agreement with Cai et al (2012) who found that no significant differences in weight gain, when they used diets supplemented with $0.0,0.3,0.5,1.0$, or $2.0 \mathrm{mg} / \mathrm{kg}$ of nano Se. Boostani et al (2015a) observed that different sources of Se (organic Se (Sel-Plex), inorganic Se (sodium selenite) and nono-selenium) under oxidative and non-oxidative conditions had no effect on daily gain. Mohamed et al (2016) compared different sources of selenium, sodium selenite, organic (Selenium Yeast) and nano selenium, and found that no significant effect on body weight gain of broiler chicks as a result of supplementing nano selenium to the diet during the periods of $12-16$ weeks of age compared to sodium selenite.

On the contrary, Wang (2009) showed that compared with the control, Se supplementation remarkably improved daily weight gain . However, no significant difference was observed between sources of Se, when they compared three treatment were fed with diets containing $0.2 \mathrm{mg} / \mathrm{kg}$ sodium selenite, $0.2 \mathrm{mg} / \mathrm{kg}$ nano-Se, and $0.5 \mathrm{mg} / \mathrm{kg} /$ nano-Se, and the control groups were fed basal diets without $\mathrm{Se}$ addition.
Zhou and Wang (2011) supplemented 0, 0.1, 0.3 , and $0.5 \mathrm{mg} / \mathrm{kg}$ of nano-Se in diets fed to Guangxi Yellow broilers and found that initial body weight did not differ significantly across the treatment groups. However, daily body weight gain was observed in the T-2 (0.3) and T-3 (0.5) groups than other groups, but no significant differences were found between the T-2 and T-3 groups. Bagheri et al (2015) supplemented diets containing sodium selenite (SS), L-selenomethionine (L-Se-Me) and Nano-Selenium (Nano-Se) with levels 0.2 and 0.5 $\mathrm{mg} / \mathrm{kg}$ for each treatment and showed that increase final average daily gain and decrease feed conversion ratio of groups supplemented with Nano-Se compared with the two other groups. Tabeidian et al (2015) investigate the effect of dietary supplementation of nano-elemental selenium (SN) compared with selenium-enriched yeast (SY) and sodium selenite (SS) and each selenium source included two levels ( 0.2 and $0.5 \mathrm{mg} / \mathrm{kg}$ ) and found that there was a significant increase in body weight gain by SN supplementation at $0.5 \mathrm{mg} / \mathrm{kg}$ compare to other treatments. Hu et al (2012) administrated $0.15,0.30,0.60$ and $1.20 \mathrm{mg} / \mathrm{kg}$ dietary Se from nano- Se or sodium selenite to diet and showed that average daily gain, gain/feed for Nano Se group reached a plateau at the Se concentration of $0.15-1.20 \mathrm{mg} / \mathrm{kg}$. However no significant different was found between the two sources of Se.

Table 3. Effect of in ovo feeding of selenomethionine and nano selenium at different levels on body weights gain of broilers (0-5 weeks)

\begin{tabular}{|c|c|c|c|c|c|c|}
\hline \multirow{2}{*}{ Treatments } & \multicolumn{7}{|c|}{ Body weight gain (g/week) } \\
\cline { 2 - 7 } & $\mathbf{1 w k}$ & $\mathbf{2 ~ w k}$ & $\mathbf{3} \mathbf{~ w k}$ & $\mathbf{4} \mathbf{~ w k}$ & $\mathbf{5} \mathbf{~ w k}$ & $\mathbf{0 - 5} \mathbf{~ w k}$ \\
\hline Control & $81.73^{\mathrm{abc}}$ & $223.48^{\mathrm{a}}$ & $384.17^{\mathrm{b}}$ & $545.90^{\mathrm{b}}$ & $477.17^{\mathrm{bc}}$ & $1675.50^{\mathrm{ab}}$ \\
PBS & $74.15^{\mathrm{c}}$ & $220.68^{\mathrm{ab}}$ & $393.12^{\mathrm{b}}$ & $547.61^{\mathrm{b}}$ & $555.88^{\mathrm{a}}$ & $1738.12^{\mathrm{ab}}$ \\
Se Me 50 & $78.08^{\mathrm{bc}}$ & $220.02^{\mathrm{ab}}$ & $396.70^{\mathrm{b}}$ & $503.62^{\mathrm{c}}$ & $502.65^{\mathrm{b}}$ & $1654.41^{\mathrm{b}}$ \\
Se Me 100 & $85.16^{\mathrm{ab}}$ & $220.01^{\mathrm{ab}}$ & $391.04^{\mathrm{b}}$ & $598.16^{\mathrm{a}}$ & $541.79^{\mathrm{a}}$ & $1753.86^{\mathrm{a}}$ \\
Nano-Se 10 & $88.77^{\mathrm{a}}$ & $198.35^{\mathrm{b}}$ & $403.24^{\mathrm{b}}$ & $572.14^{\mathrm{ab}}$ & $506.25^{\mathrm{b}}$ & $1729.25^{\mathrm{ab}}$ \\
Nano-Se 20 & $79.63^{\mathrm{abc}}$ & $203.37^{\mathrm{ab}}$ & $438.50^{\mathrm{a}}$ & $483.00^{\mathrm{c}}$ & $460.30^{\mathrm{c}}$ & $1664.80^{\mathrm{b}}$ \\
\hline SEM & $\mathbf{3 . 2 4}$ & $\mathbf{7 . 0 6}$ & $\mathbf{8 . 7 8}$ & $\mathbf{9 . 7 2}$ & $\mathbf{9 . 7 6}$ & $\mathbf{2 7 . 5 8}$ \\
\hline
\end{tabular}

a, b, c means within the same column with different superscript are significantly different $(P \leq 0.0001)$.

\section{c. Feed intake and feed conversion ratio.}

Effect of in ovo feeding of selenomethionine and nano selenium at different levels on feed intake and feed conversion ratio (FCR) of broilers (0-5 weeks)are presented in Tables (4 and 5$)$. It is apparent that feed intake and feed conversion were not affected $(P>0.05)$ by Se source or level of supplementation except at 2 wks of age, in which average feed intake and feed conversion were decrease in nano Se groups significantly compared to control. 
Table 4. Effect of in ovo feeding of selenomethionine and nano selenium at different levels on feed intake ( $\mathrm{g} / \mathrm{bird} / \mathrm{week})$ of broilers (0-5 weeks)

\begin{tabular}{|c|c|c|c|c|c|c|}
\hline \multirow{2}{*}{ Treatments } & \multicolumn{7}{|c|}{ Feed Intake } \\
\cline { 2 - 7 } & $\mathbf{1 w k}$ & $\mathbf{2 ~ w k}$ & $\mathbf{3} \mathbf{~ w k}$ & $\mathbf{4} \mathbf{w k}$ & $\mathbf{5 ~ w k}$ & $\mathbf{0 - 5} \mathbf{~ w k}$ \\
\hline Control & 99.96 & $335.59^{\mathrm{ab}}$ & $566.46^{\mathrm{ab}}$ & 787.59 & 929.36 & 2717.37 \\
PBS & 87.65 & $313.13^{\mathrm{bc}}$ & $557.71^{\mathrm{b}}$ & 793.33 & 947.43 & 2694.08 \\
Se Me 50 & 87.68 & $341.51^{\mathrm{ab}}$ & $558.13^{\mathrm{b}}$ & 811.67 & 882.85 & 2682.43 \\
Se Me 100 & 92.23 & $355.10^{\mathrm{a}}$ & $565.63^{\mathrm{ab}}$ & 749.59 & 993.21 & 2758.57 \\
Nano-Se 10 & 98.09 & $297.20^{\mathrm{c}}$ & $602.75^{\mathrm{ab}}$ & 776.46 & 1118.47 & 2886.59 \\
Nano-Se 20 & 91.57 & $298.77^{\mathrm{c}}$ & $624.44^{\mathrm{a}}$ & 747.78 & 957.92 & 2716.71 \\
\hline SEM & $\mathbf{4 . 5 2}$ & $\mathbf{8 . 8 3}$ & $\mathbf{1 8 . 8 0}$ & $\mathbf{3 5 . 2 3}$ & $\mathbf{4 0 . 7 1}$ & $\mathbf{9 2 . 5 5}$ \\
\hline
\end{tabular}

$a, b, c$ means within the same column with different superscript are significantly different $(P \leq 0.0001)$.

Similar results were observed in other studies by Cai et al (2012) who found that no significant differences in feed intake, and feed conversion when they used diets supplemented with 0.0, 0.3, $0.5,1.0$, or $2.0 \mathrm{mg} / \mathrm{kg}$ of nano Se. Bakyaraj et al (2012). Reported that there was no significant $(p<0.05)$ difference observed in feed conversion ratio of in ovo trace elements injected chicks. Boostani et al (2015a) observed that different sources of Se (organic Se (Sel-Plex), inorganic Se (sodium selenite) and nono-selenium) under oxidative and non-oxidative conditions had no effect on feed intake and FCR. Tabeidian et al (2015) investigate the effect of dietary supplementation of nano-elemental selenium (SN) compared with selenium-enriched yeast (SY) and sodium selenite (SS) and each selenium source included two levels $(0.2$ and $0.5 \mathrm{mg} / \mathrm{kg}$ ) and found that feed conversion ratio was not affected by dietary treatments. Choupani et al (2014) observed that no significant difference in feed intake and feed conversion ratio between nano Se and sodium selenite or selenomethionine groups, when the basal diet was supplemented with 0 (control) or $0.3 \mathrm{mg} / \mathrm{kg}$ Se from sodium selenite, selenomethionine, selenized yeast or nano elemental selenium

In contrast, El Said (2015) administration nano Se with different levels (20 and $40 \mathrm{ppb}$ ) at 7 and 14 days of incubation for each level in egg and found that increase feed consumption and feed conversion of nano-Se groups compare to control. However, no significant difference between the two levels or between two injection time.

El-Deep et al (2016) compared three dietary supplementation [(basal diet without Se supple- mentation (control), $0.3 \mathrm{mg}$ of Nanoelemental Se per kilogram of diet (nano-Se), and $0.3 \mathrm{mg}$ of sodium selenite per kilogram of diet (SSe)] under the ambient temperature challenge $\left(22 \pm 1^{\circ} \mathrm{C}\right.$ or $35 \pm 1^{\circ} \mathrm{C}$ ) from 15 to $30 \mathrm{~d}$ of age, and they found dietary supplementation with nano-Se $(0.3 \mathrm{mg} / \mathrm{kg}$ diet) improve feed conversion ratio under high ambient temperature conditions. Konkov et al (2015) used nano selenium at concentration of $0.1,0.01$ and $0.001 \mathrm{mg} / \mathrm{kg}$ of daily live weight and indicated that decrease feed intake in all groups compared with the control,and the optimal concentration of nano selenium is $0.001 \mathrm{microgr} / \mathrm{kg}$ of a bird weight Wang (2009) showed that compared with the control, Se supplementation remarkably decreased feed conversion ratio. However, no significant difference was observed between sources of Se, when they compared with those fed diets containing $0.2 \mathrm{mg} / \mathrm{kg}$ sodium selenite, $0.2 \mathrm{mg} / \mathrm{kg}$ nano-Se, and $0.5 \mathrm{mg} / \mathrm{kg} / \mathrm{nano}-\mathrm{Se}$, and the control group fed basal diets without Se addition. Radwan et al (2015) supplied two sources of Se (sodium selenite and nano-Se) and 3 levels of each source $(0.10,0.25$ and $0.40 \mathrm{ppm})$ and showed that different Se levels of sodium selenite or nano-Se did not affect feed intake. However, the feed conversion ratio significantly improved, by adding nano-Se in layer diets. Bagheri et al (2015) supplemented diets containing sodium selenite (SS), Lselenomethionine (L-Se-Me) and nano-Selenium (Nano-Se) with levels 0.2 and $0.5 \mathrm{mg} / \mathrm{kg}$ for each treatment and showed that decrease feed conversion ratio of groups supplemented with nano-Se compared with the two other groups. 

on growth performance and physiological parameters of broiler chicks

Table 5. Effect of in ovo feeding of selenomethionine and nano selenium at different levels on feed conversion of broilers (0-5 weeks)

\begin{tabular}{|c|c|c|c|c|c|c|}
\hline \multirow{2}{*}{ Treatments } & \multicolumn{7}{|c|}{ Feed Conversion } \\
\cline { 2 - 6 } & $\mathbf{1 w k}$ & $\mathbf{2 ~ w k}$ & $\mathbf{3} \mathbf{w k}$ & $\mathbf{4} \mathbf{~ w k}$ & $\mathbf{5} \mathbf{~ w k}$ & $\mathbf{0 - 5} \mathbf{~ w k}$ \\
\hline Control & 1.223 & $1.501^{\mathrm{ab}}$ & 1.474 & $1.442^{\mathrm{abc}}$ & $1.947^{\mathrm{abc}}$ & 1.622 \\
PBS & 1.182 & $1.419^{\mathrm{b}}$ & 1.418 & $1.449^{\mathrm{abc}}$ & $1.704^{\mathrm{c}}$ & 1.550 \\
Se Me 50 & 1.123 & $1.552^{\mathrm{ab}}$ & 1.407 & $1.611^{\mathrm{a}}$ & $1.756^{\mathrm{c}}$ & 1.621 \\
Se Me 100 & 1.083 & $1.614^{\mathrm{a}}$ & 1.446 & $1.253^{\mathrm{c}}$ & $1.833^{\mathrm{bc}}$ & 1.573 \\
Nano-Se 10 & 1.105 & $1.450^{\mathrm{c}}$ & 1.495 & $1.357^{\mathrm{bc}}$ & $2.209^{\mathrm{a}}$ & 1.669 \\
Nano-Se 20 & 1.150 & $1.469^{\mathrm{b}}$ & 1.424 & $1.548^{\mathrm{ab}}$ & $2.081^{\mathrm{ab}}$ & 1.632 \\
\hline SEM & $\mathbf{0 . 0 5 3}$ & $\mathbf{0 . 0 4 2}$ & $\mathbf{0 . 0 4 7}$ & $\mathbf{0 . 0 6 4}$ & $\mathbf{0 . 0 8 2}$ & $\mathbf{0 . 0 6 9}$ \\
\hline
\end{tabular}

$a, b, c$ means within the same column with different superscript are significantly different ( $P \leq 0.0001)$.

\section{Blood parameters}

\section{a. Blood metabolites}

Effect of in ovo feeding of selenomethionine and nano selenium at different levels on total protein, albumin and globulin concentrations in plasma of broilers (0-5 weeks) are presented in Table (6). It could be observed that nano groups and Se100 were higher in total protein than control. On other hand, albumin level was significantly increased in Nano Se 20 and SeMe 100 groups compared to control. However, no significant difference between sources of Se or between levels in both concentrations of total protein and albumin. Moreover, no differences were noted between Se sources and control in globulin and $A / G$.

Table 6. Effect of in ovo feeding of selenomethionine and nano selenium at different levels on total protein, albumin and globulin concentrations in plasma of broilers ( $0-5$ weeks)

\begin{tabular}{|c|c|c|c|c|}
\hline \multirow{2}{*}{ Treatments } & \multicolumn{4}{|c|}{ Blood Constituents } \\
\cline { 2 - 5 } & $\begin{array}{c}\text { Total } \\
\text { Protein } \\
(\mathbf{g} / \mathbf{d l})\end{array}$ & $\begin{array}{c}\text { Albumin } \\
\mathbf{( g / d \mathbf { l } )}\end{array}$ & $\begin{array}{c}\text { Globulin } \\
\mathbf{( g / d l )}\end{array}$ & $\mathbf{A} / \mathbf{G}$ \\
\hline Control & $3.16^{\mathrm{c}}$ & $1.74^{\mathrm{b}}$ & $1.41^{\mathrm{b}}$ & 1.26 \\
PBS & $3.94^{\mathrm{a}}$ & $2.19^{\mathrm{a}}$ & $1.74^{\mathrm{a}}$ & 1.27 \\
Se Me 50 & $3.40^{\mathrm{bc}}$ & $1.99^{\mathrm{ab}}$ & $1.50^{\mathrm{ab}}$ & 1.30 \\
Se Me 100 & $3.81^{\mathrm{ab}}$ & $2.18^{\mathrm{a}}$ & $1.62^{\mathrm{ab}}$ & 1.40 \\
Nano-Se 10 & $3.54^{\mathrm{ab}}$ & $1.95^{\mathrm{ab}}$ & $1.58^{\mathrm{ab}}$ & 1.26 \\
Nano-Se 20 & $3.62^{\mathrm{ab}}$ & $2.19^{\mathrm{a}}$ & $1.43^{\mathrm{b}}$ & 1.63 \\
\hline SEM & $\mathbf{0 . 1 3 7}$ & $\mathbf{0 . 1 0}$ & $\mathbf{0 . 0 9}$ & $\mathbf{0 . 1 3 0}$ \\
\hline
\end{tabular}

$a, b, c$ means within the same column with different superscript are significantly different $(P \leq 0.0001)$.
These results are in agreement with Mohamed et al (2016) who found that dietary supplementation of nano selenium resulted in a significant increase in plasma total protein and globulin. However, albumin was not significantly affected. Mohapatra et al (2014) showed that serum total protein and globulin levels were increased linearly and quadratically in nano Se supplemented group at 8 weeks of age compared to sodium selenite group, whereas, A/G ratio was decreased. In addition, serum albumin of layer chicks showed no significant difference between sources of Se. El-Said (2015) found a significant increase of globulin in nano Se 40 ppb group, but there was no effect with group of nano Se $20 \mathrm{ppb}$. On other hand, no significant effect of total protein and albumin compared to control. Selim et al (2015) demonstrated that no significant effect of nano-Se at 0.15 and $0.30 \mathrm{ppm}$ in diet or drinking water on plasma total proteins, albumin, globulins and albumin/globulins ratio.

Effect of in ovo feeding of selenomethionine and nano selenium at different levels on total cholesterol, triglycerides, high-density lipoprotein (HDL) and glucose concentrations in plasma of broilers (0-5 weeks) are presented in Table (7). The data show that group Se100 recorded higher levels for total cholesterol than in other treatments. However, nano Se 20 was higher in HDL than other groups. On other hand, there was a significant decline in plasma glucose due to injection of nano se compare to control, but no difference was observed among Se sources. In addition, there were no differences between treatments in triglycerides levels. 
Table 7. Effect of in ovo feeding of selenomethionine and nano selenium at different levels on total cholesterol, triglycerides, high-density lipoprotein (HDL) and glucose concentrations in plasma of broilers (0-5 weeks)

\begin{tabular}{|c|c|c|c|c|}
\hline \multirow{2}{*}{ Treatments } & \multicolumn{4}{|c|}{ Blood Constituents } \\
\cline { 2 - 5 } & $\begin{array}{c}\text { Cholesterol } \\
\text { (mg/dl) }\end{array}$ & $\begin{array}{c}\text { TG } \\
\text { (mg/dl) }\end{array}$ & $\begin{array}{c}\text { HDL } \\
\text { (mg/dl) }\end{array}$ & $\begin{array}{c}\text { Glucose } \\
\text { (mg/dl) }\end{array}$ \\
\hline Control & $90.73^{\mathrm{b}}$ & 66.70 & $64.67^{\mathrm{b}}$ & $289.86^{\mathrm{a}}$ \\
PBS & $69.89^{\mathrm{c}}$ & 58.72 & $48.90^{\mathrm{c}}$ & $224.52^{\mathrm{b}}$ \\
Se Me 50 & $91.47^{\mathrm{b}}$ & 74.38 & $52.25^{\mathrm{c}}$ & $253.98^{\mathrm{ab}}$ \\
Se Me 100 & $104.33^{\mathrm{a}}$ & 67.64 & $62.37^{\mathrm{b}}$ & $261.36^{\mathrm{ab}}$ \\
Nano-Se 10 & $88.75^{\mathrm{b}}$ & 64.58 & $64.07^{\mathrm{b}}$ & $243.71^{\mathrm{b}}$ \\
Nano-Se 20 & $87.04^{\mathrm{b}}$ & 67.59 & $76.92^{\mathrm{a}}$ & $237.24^{\mathrm{b}}$ \\
\hline SEM & $\mathbf{4 . 4 9}$ & $\mathbf{5 . 0 7}$ & $\mathbf{2 . 6 0}$ & $\mathbf{1 3 . 1 4}$ \\
\hline
\end{tabular}

$a, b, c$ means within the same column with different superscript are significantly different $(P \leq 0.0001)$.

These results are in agreement with Mohapatra et al (2014) showed that serum glucose was increased linearly and quadratically in nano Se supplemented group at 8 weeks of age compare to sodium selenite group. Whereas, serum cholesterol and triglyceride, decreased. Radwan et al (2015) found that nano-Se significantly reduced total cholesterol and increased HDL-cholesterol to total cholesterol ratio in maternal hens (plasma and yolk). Boostani et al (2015b) observed that no significant difference in level of cholesterol and glucose between organic Se (Sel-Plex), inorganic Se (sodium selenite) and nono-selenium under oxidative stress. El-Said (2015) found that there was a significant increase of HDL in nano Se 40 $\mathrm{ppb}$, but no effect with group of nano Se $20 \mathrm{ppb}$. However, significant decrease of glucose, triglyceride, total cholesterol were shown. Saleh (2014) found that plasma total cholesterol, triglyceride, and glucose levels occurred lower $(P<0.05)$ by feeding the compound of $A$. awamori and selenium nano-particles compared to control group, while plasma HDL-cholesterol increased.

\section{REFERENCES}

AAFCO. 2011. AAFCO Model Guidance Document. Official guidelines suggested for contaminants in individual mineral feed ingredients. Official publication. Association of American Feed Control Officials Inc., Olympia, WA, p. 304.

Bagheri, M., Golchin-Gelehdooni, S., Mohamadi, M. and Tabidian, A. 2015. Comparative effects of nano, mineral and organic selenium on growth performance, immunity responses and total antioxidant activity in broiler chickens. Int. J. of Biology Pharmacy and Allied Sci., 4(2), 583-595.

Bakyaraj, S., Bhanja, S.K., Majumdar, S. and Dash, B. 2012. Modulation of post-hatch growth and immunity through in ovo supplemented nutrients in broiler chickens. J. Sci. Food Agric., 92, 313-320.

Baure, J.D. 1982. Clinical Laboratory Methods. $9^{\text {th }}$ Ed., C.V. Mosby Co., pp. 495-496.

Boostani, A., Sadeghi, A.A., Mousavi, S.N., Chamani, M. and Kashan, N. 2015a. Effects of organic, inorganic, and nano-Se on growth performance, antioxidant capacity, cellular and humoral immune responses in broiler chickens exposed to oxidative stress. Livestock Science, 178, 330-336.

Boostani, A., Sadeghi, A.A., Mousavi, S.N., Chamani, M. and Kashan, N. 2015b. The effects of organic, inorganic, and nano-selenium on blood attributes in broiler chickens exposed to oxidative stress. Acta Scientiae Veterinaria, 43, 1-6.

Cai, S.J., Wu, C.X., Gong, L.M., Song, T., Wu, H. and Zhang, L.Y. 2012. Effects of nanoselenium on performance, meat quality, immune function, oxidation resistance, and tissue selenium content in broilers. Poult. Sci., 91(10), 2532-2539

Choct, M., Naylor, A.J. and Reinke, N. 2004. Selenium supplementation affects broiler growth performance, meat yield and feather coverage. Br. Poult. Sci. 45, 677-683.

Choupani, M., Parmiss, Z.M., Hamid, R.K. and Shahab, G. 2014. Influence of dietary selenium sources on thyroid hormone activation, tissue selenium distribution and antioxidant enzymes status in broiler chickens. DAMA International, 3, 281-297.

Dlouha, G., Sevcikova, S., Dokoupilova, A., Zita, L., Heindl, J. and Skrivan, M. 2008. Effect of dietary selenium sources on growth performance, breast muscle selenium, glutathione peroxidase activity and oxidative stability in broilers. Czech Journal of Animal Science, 53, 265-269.

Dumas, B.T. and Biggs, H.G.1972. Standard Methods Clinical Chemistry Vol. 7. Academic Press, New York, USA, 175 p.

Edens, F.W., Parkhurst, C.R., Havenstein, G.B. and Sefton A.E. 2001. Housing and selenium influences on feathering on broilers. J. Appl. Poult. Res., 10, 128-134. 
El-Deep, M.H., Daichi, I., Tarek, A.E. and Akira, O. 2016. Effects of Dietary Nano-Selenium Supplementation on Growth Performance, Antioxidative Status, and Immunity in Broiler Chickens under Thermoneutral and High Ambient Temperature Conditions. J. Poult. Sci., 53, 274-283

El-Said, 2015. Influence of in-ovo injection (feeding) with Nano particles Selenium (SeNPs) on growth performance, carcass yield and immune status of broiler chickens. Ph.D. Thesis. Fac. Agric., Damietta Univ., Egypt, pp. 48-102.

European Union. 2004. List of the authorized additives in feeding stuffs published in application of Article 9t (b) of Council Directive 70/524/EEC concerning additives in feeding stuffs. Off. J. Eur. Union. C/50, 43 p.

European Union. 2006. Concerning the authorization of selenomethionine as a feed additive. Off. J. Eur. Union. L/330, pp. 9-11.

Federal Register. 2002. Food additives permitted in feed and drinking water: Selenium yeast. Fed. Regist. 67, 46850-46851.

Fossati, P. and Prencipe, L. 1982. The determination of triglyceride using enzymatic methods. Clin. Chem., 28, 2077-2080.

Halliwell, B. 1994. Free radicals and antioxidants: A personal view. Nutr. Rev. 52(8), 253-265.

Hansen, P.W. 1966. A simplification of kind and King's method for determination of serum phosphatase. Scand. J. Clin. Lab. Invest., 18, 353-356.

Heindl, J., Ledvinka, Z., Englmaierova, M., Zita, L. and Tumova, E. 2010. The effect of dietary selenium sources and levels on performance, selenium content in muscle and glutathione peroxidase activity in broiler chickens. Czech Journal of Animal Science, 55, 572-578.

Hu, H.C., Li, Y.L., Xiong, L., Zhang, H.M., Song, J. and Xia, M.S. 2012. Comparative effects of nano elemental selenium and sodium selenite on selenium retention in broiler chickens. Animal Feed Science and Technology, 177, 204-210.

Josephson, B. and Gyllensward, C. 1957. Total protein kit. Scand. J. Clin. Lab. Inverst., 9, 29.

Konkov, A.A., Ampleeva, L.V., Polishchuk, S.D. and Churilov, G.I. 2015. Investigation of Nano Selenium Influence on Productivity and Hematological Exponents of Broiler Chickens. Modern Applied Science; 9(13), 36-43.

Lopes-Virella, M.F., Stone, S., Ellis, S. and Collwel, J.A. 1977. Cholesterol determination in high density lipoproteins separated by three different methods. Clin. Chem., 23, 882-884.

Mervyn, L. 1985 . The Dictionary of Minerals: The Complete Guide to Minerals and Mineral Therapy. L. Mervyn, ed. pp. 173-177. Lothian Publishing، Melbourne, Australia.

Ministry of Agriculture. 2008. Ministry of Agriculture of People's Republic of China Bulletin No. 1226-2008. Approved feed additives. Beijing, China. Cited by Cai et al 2012.

Ministry of Agriculture. 2010. Ministry of Agriculture of People's Republic of China Bulletin No. 1224-2010. The safety use standard of feed additives. Beijing, China, Cited by Cai et al 2012.

Mohamed, H.S., Rizk, Y.S., El-Slamony, A.E., Soliman, A.A. and Ibrahim, A.F. 2016. Study the relationship between selenium and heat shock proteins under heat stress for local sinai chickens strain. Egypt. Poult. Sci. 36(I), 337354.

Mohapatra, P., Swain, R.K., Mishra, S.K., Behera, T., Swain, P., Mishra, S.S., Behura, N.C., Sabat, S.C., Sethy, K., Dhama, K. and Jayasankar, P. 2014. Effects of dietary nanoselenium on tissue selenium deposition, antioxidant status and immune functions in layer chicks. Int. J. Pharmacol., 10, 160-167.

NRC. 1994. Nutrient Requirements of Poultry. $9^{\text {th }}$ rev. ed. Natl. Acad. Press, Washington, DC. $31 \mathrm{p}$.

Payne, R.L. and Southern, L.L.2005. Comparison of inorganic and organic Se sources for broilers. Poult. Sci. 84(6), 898-902.

Radwan, N.L., Salah Eldin, T.A., EL-Zaiat, A.A. and Mostafa, Mona A.S.A. 2015. Effect of Dietary Nano-Selenium Supplementation on Selenium Content and oxidative Stability in Table Eggs and Productive Performance of Laying Hen. International Journal of Poultry Science, 14(3), 161-176.

Rotruck, J.T., Pope, A.L., Ganther, H.E., Swanson, A.B., Hafeman, D.G. and Hoekstra, W.G. 1973. Selenium: biochemical role as a component of glutathione peroxidase. Science 179, 588-590.

Rozbicka-Wieczorek, A.J., Szarpak, E., Brzoska, F., Sliwinski, B., Kowalczyk, J. and Czauderna, M. 2012. Dietary lycopenes, selenium compounds and fish oil affects the profile of fatty acids and oxidative stress in chicken breast muscle. Journal of Animal Feed Sciences, 21, 705-724. 
Saleh 2014. Effect of dietary mixture of Aspergillus probiotic and selenium nano-particles on growth, nutrient digestibilities, selected blood parameters and muscle fatty acid profile in broiler chickens. Animal Science Papers and Reports 32(1), 65-79.

SAS, Statistical Analysis System, 1999. User's Guide. Version 6.12, Cary, NC, USA

Selim, N.A., Radwan, N.L., Youssef, S.F., Salah Eldin, T.A. and Abo Elwata, S. 2015. Effect of inclusion inorganic, organic or nano selenium forms in broiler diets on: 2-Physiological, immunological and toxicity statuses of broiler chicks. International Journal of Poultry Science 14(3), 144-155.

Senthil, K.C.K., Sugapriya. S., Dhayalan Velauthapillai, R. Ranjithkumar and Chandarshekar B. 2015. Influence of Dietary Selenium Nanowires on Growth Performance of Broiler Chicken. International Journal of Biosciences and Nanosciences. 2(4), 78-83.

Steinberg, D. 1981. Metabolism of lipoproteins at the cellular level in relation to atherogenesis. In lipoproteins. Atherosclerosis and Coronary Heart disease, 1, 31-48.

Surai, P.F., Noble, R.C. and Speake, B.K. 1996. Tissue-specific differences in antioxidant distribution and susceptibility to lipid peroxidation during development of the chick embryo. Biochim Biophysica Acta. 1304, 1-10.

Surai, P.F and Dvorska, J.E. 2002. Effect of selenium and vitamin $E$ content of the diet on lipid peroxidation in breast muscle tissue of broiler breeder hens during storage. Australian Poultry Science Symposium, 14, 187-192

Tabeidian, S.A., Meysam, B. and Amir, D.F. 2015. Effects of different selenium sources on performance, immune responses, and antioxidant status of broiler chickens. The IRES 4th International Conference, Kuala Lumpur, Malaysia. pp. 84-87.

Wang, Y. 2009. Differential effects of sodium selenite and nano-Se on growth performance, tissue Se distribution, and glutathione peroxidase activity of avian broiler," Biol Trace Elem Res, 128(2), 184-190.

Wang, H., Zhang, J. and Yu, H. 2007. Elemental selenium at nano size possesses lower toxicity without compromising the fundamental effect on selenoenzymes: Comparison with selenomethionine in mice. Free Radic. Biol. Med. 42, 1524-1533.

Zhang, J.S., Wang, X.F. and Xu, T.W. 2008. Elemental selenium at nano size (nano-Se) as a potential chemopreventive agent with reduced risk of selenium toxicity: Comparison with Semethylselenocysteine in mice. Toxicol. Sci. 101, 22-31.

Zhou, X. and Wang, Y. 2011. Influence of dietary nano elemental selenium on growth performance, tissue selenium distribution، meat quality, and glutathione peroxidase activity in Guangxi Yellow chicken. Poult. Sci. 90, 680686. 